\title{
A new sudden decline disease of bullet wood in Thailand is associated with Ceratocystis manginecans
}

\author{
Chaninun Pornsuriya ${ }^{1} \cdot$ Anurag Sunpapao ${ }^{1}$
}

Received: 16 August 2014 / Accepted: 23 July 2015 /Published online: 4 August 2015

(C) Australasian Plant Pathology Society Inc. 2015

\begin{abstract}
In Thailand, since 2013, sudden decline of bullet wood (Mimusops elengi) has been noted. The causal agent of this disease was identified based on both morphological and molecular properties as Ceratocystis manginecans. A portion of its ITS, $\beta$-tubulin and TEF1- $\alpha$ genes were amplified by PCR with the universal primer pairs PN3/PN16, $\beta \mathrm{t} 1 \mathrm{a} / \beta \mathrm{t} 1 \mathrm{~b}$ and EF1-728F/EF1-986R, respectively. Sequencing of the PCR product confirmed this pathogen was $C$. manginecans. This is the first report on the new sudden decline disease of bullet wood in Thailand associated with $C$. manginecans.
\end{abstract}

Keywords Mimusops elengi · PCR · Phytopathogenic fungi · Universal primers

Bullet wood (Mimusops elengi) belongs to the family Sapotaceae, and it is known in Thailand as "Pikul". These trees range from small to large, and are found in all parts of Thailand where bullet wood is cultivated in gardens as an ornamental tree, and planted along avenues because of its fragrant flowers. Bullet wood is a medicinally important plant; its bark has anti-inflammatory properties, along with analgesic and antipyretic activities (Purnima et al. 2010).

In 2013, wilt and dieback symptoms were observed for the first time on $M$. elengi in the grounds of Prince of Songkla University, Hatyai, Songkhla, Thailand. The aim of this study was to identify the causal agent of this sudden decline disease of bullet wood. Sap stain moulds were isolated from infected

Anurag Sunpapao

anurag.su@psu.ac.th

1 Department of Pest Management, Faculty of Natural Resources, Prince of Songkla University, Hatyai, Songkhla 90112, Thailand bullet wood, and identified based on morphological characteristics and molecular analysis.

The bullet wood branches were cut transversely and longitudinally and had red to dark red internal discoloration (Fig. 1e and f). Bark beetle emergence holes on the trunks of infected bullet wood were also found (Fig. 1d, arrows). Symptomatic wood pieces were extracted by cutting, sealed in plastic bags, and transported in cooler boxes to the laboratory where isolations were conducted immediately. Three sections of $1-3 \mathrm{~cm}$ in length were cut from the margins of lesions, including some healthy wood. These wood sections were surface-sterilised with rapid scorching in a flame. The wood samples were then placed on potato dextrose agar (PDA), and the agar plates were incubated for 10 days at room temperature. The fungal colonies were subcultured on PDA, and incubated for 10 days. Single spore subcultures were maintained for routine use on PDA slants.

The isolated fungi were initially identified based on morphological characteristics of a 10 day old culture. The sexual and asexual state of the fungus were mounted in lactophenol on glass slides, and examined by light microscopy. The white hypha of colonies emerged from infected tissue after a $72 \mathrm{~h}$ incubation. Isolates of the fungus grew slowly on PDA with ethylene production. The fungal cultures had light grey mycelia and dark grey to greenish submerged mycelia with few observed ascomata (Fig. 2). The ascomatal bases were black and globose to subglobose (Fig. 2a), and the fungal isolates produced ascomatal necks with divergent ostiolar hyphae at their tips (Fig. 2b), from which hat-shaped ascospores were released (Fig. 2b and f). This fungus also produced young chlamydospores, chains of conidia and barrel-shaped conidia (Fig. 2c, d and e).

Based on morphological characters, the fungus was identified as Ceratocystis manginecans, a widely distributed species pathogenic on mango (Ploetz 2003). A culture of the fungus 
Fig. 1 Characteristics of sudden decline disease on bullet wood, observed at Prince of Songkla University (a), wilted leaves of bullet wood (b-c), wounded bark and bark beetle emergence holes (d, arrows), and sap stain mould on bullet wood $(\mathbf{e}-\mathbf{f})$

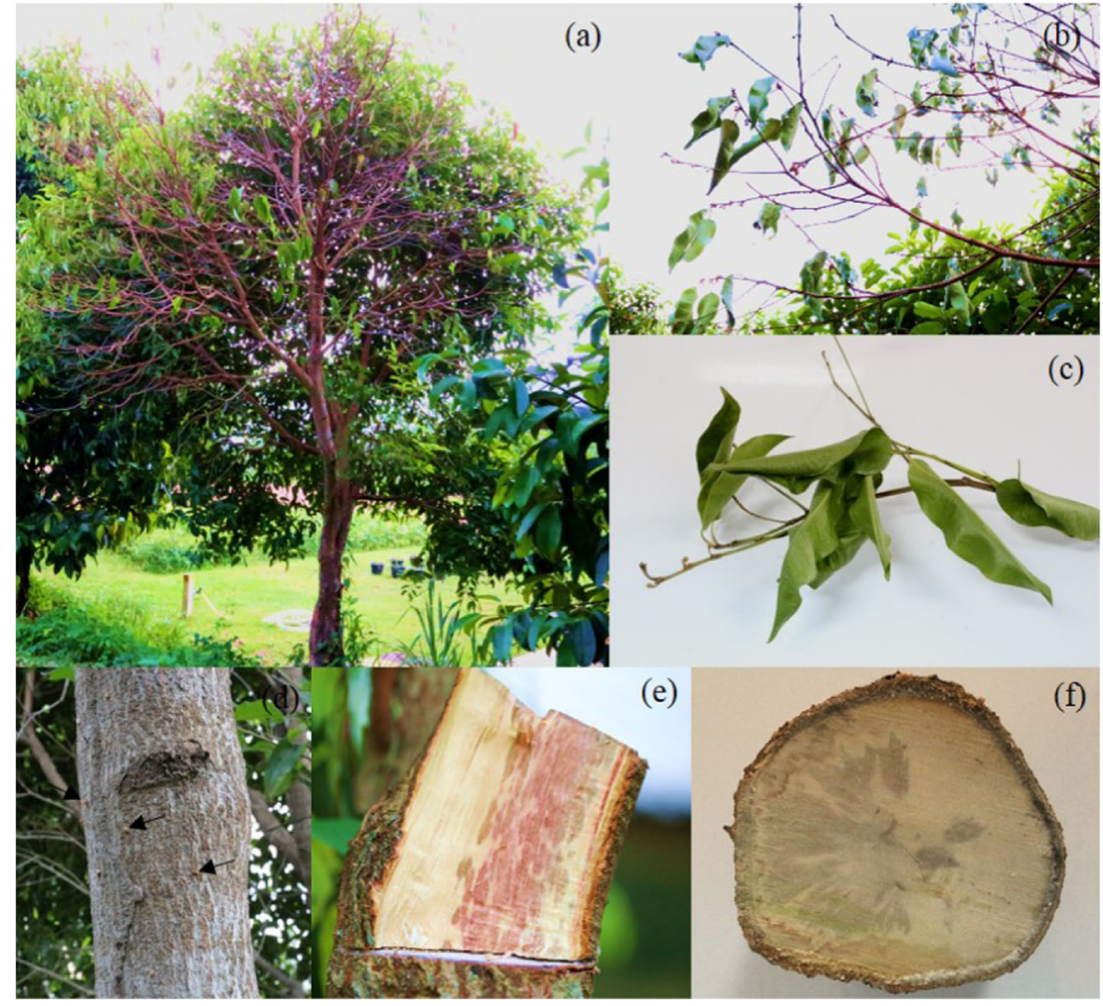

was deposited in the Culture Collection of Pest Management Department, Faculty of Natural Resources, Prince of Songkla University, Thailand, as PSU-PK01.

To confirm the species identification, isolates were cultured on PDA at room temperature for 2 weeks. Total DNA was extracted by the cetyltrimetyl ammonium bromide (CTAB) method (Kollar et al. 1990), as follows. Mycelia was collected and cleaned with sterilised distilled water (DW), and then dried and kept at $-20{ }^{\circ} \mathrm{C}$ prior to isolating the DNA. Frozen mycelia were ground to a fine powder with a small mortar and
Fig. 2 Morphological characteristics of Ceratocystis manginecans (PSU-PK01), a globose ascomata with long neck, b divergent ostiolar hyphae release ascospores (arrow), c young chlamydospore, $\mathbf{d}$ chain of conidia, e barrel-shaped conidia and $\mathbf{f}$ hat-shaped ascospores in side view. Scale bars: $\mathbf{a}=100 \mu \mathrm{m}, \mathbf{b}-\mathbf{d}=10 \mu \mathrm{m}$, $\mathbf{e}=20 \mu \mathrm{m}, \mathbf{f}=5 \mu \mathrm{m}$

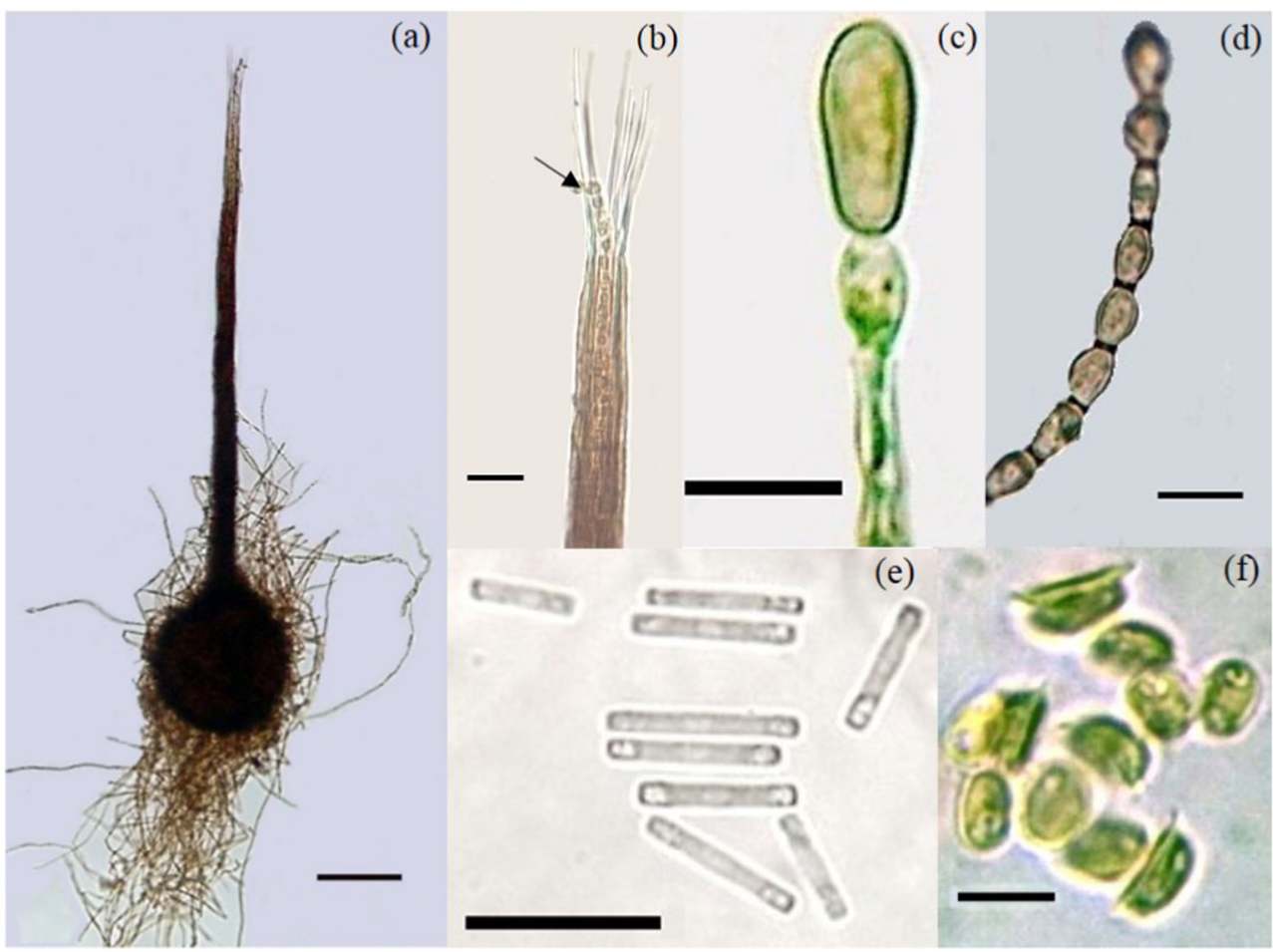


Fig. 3 Neighbour-joining tree generated using sequences of the ITS, specifically the $\beta$-tubulin and TEF1- $\alpha$ gene regions, of Ceratocystis manginecans (PSUPK01). Chaetomium globosum was included as an outgroup. The numbers at branches indicate the percentage support using 1000 bootstrap replications

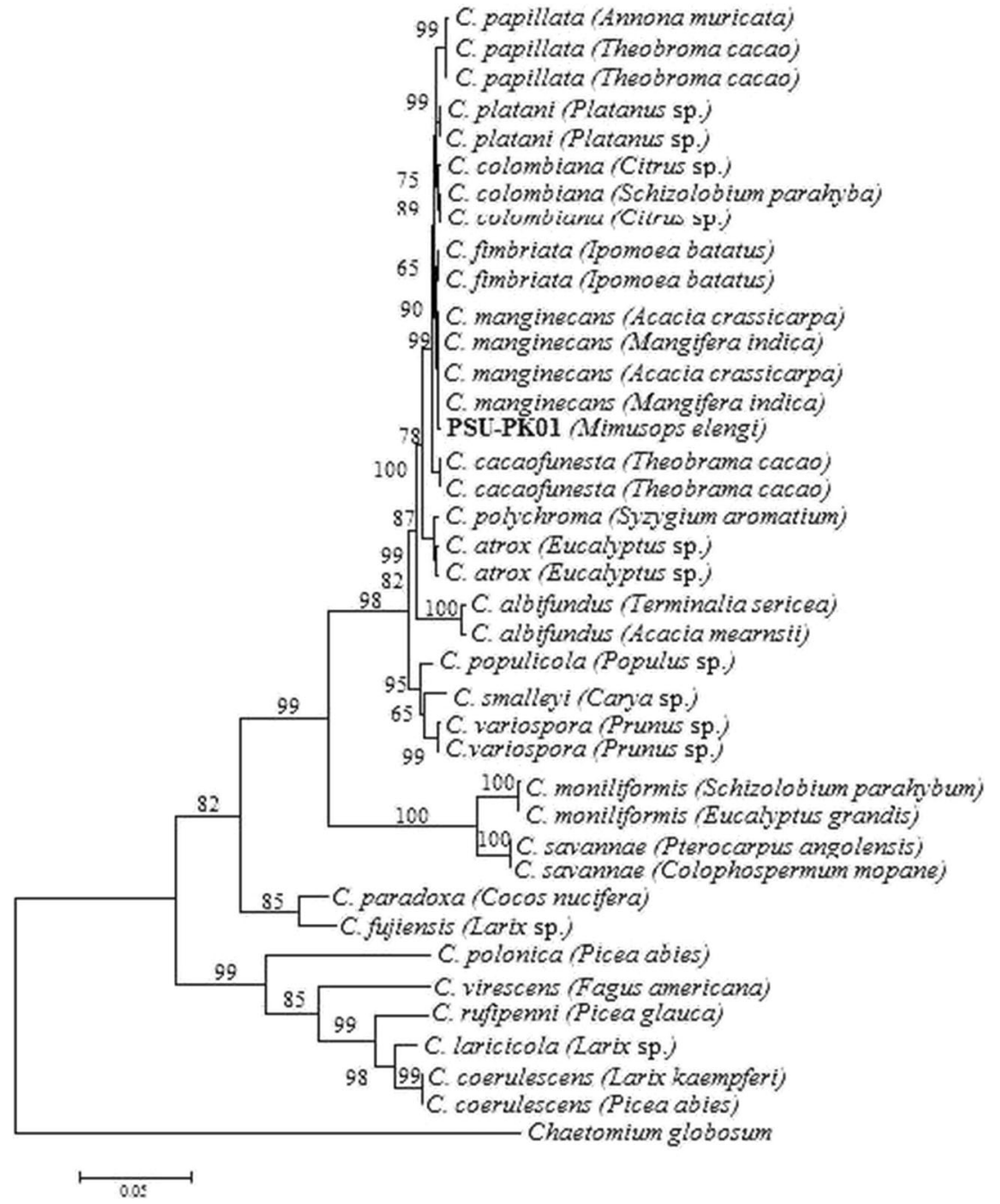

and extension for $1 \mathrm{~min}$ at $72{ }^{\circ} \mathrm{C}$, with a final extension step of $10 \mathrm{~min}$ at $72{ }^{\circ} \mathrm{C}$. The PCR products were visualised by agarose gel electrophoresis. The portion of ITS gene region was sequenced at Scientific Equipment Center, Prince of Songkla University, Songkhla, Thailand, by automated DNA sequencing with ABI Prism 377 (Applied Biosystems, USA) using the same primers used in the $\mathrm{PCR}$ reaction.

For the ITS, $\beta$-tubulin, and TEF1- $\alpha$ gene regions, PCR amplification gave fragments of about 500 base pairs in size. The sequences of the amplified products were then deposited in the GenBank database and assigned accession numbers AB905498, AB919056, AB919057 for the ITS, $\beta$-tubulin and TEF1- $\alpha$ gene, respectively, and they were compared with the sequences of $C$. manginecans available at GenBank. BLAST searches in GenBank indicated that our isolates grouped within $C$. manginecans species with $99 \%$ identity of the sequences. The phylogenetic relationships of this select isolate with closely related taxa was analysed using neighbour-joining methods. Phylogeny was assessed using a bootstrap analysis with 1000 replicates. According to the phylogenetic relationships derived 
Table 1 Ceratocystis spp. used in this study

\begin{tabular}{|c|c|c|c|c|c|c|c|}
\hline Species & Host & $\begin{array}{l}\text { GenBank } \\
\text { accession } \\
\text { number }\end{array}$ & $\begin{array}{l}\text { Geographical } \\
\text { origin }\end{array}$ & Species & Host & $\begin{array}{l}\text { GenBank } \\
\text { accession } \\
\text { number }\end{array}$ & $\begin{array}{l}\text { Geographical } \\
\text { origin }\end{array}$ \\
\hline \multirow[t]{2}{*}{ C. albifundus } & \multirow[t]{2}{*}{ Terminalia sericea } & $\begin{array}{l}\text { KC691452 } \\
\text { KC691476 }\end{array}$ & \multirow[t]{2}{*}{ South Africa } & \multirow[t]{2}{*}{ C. manginecans } & \multirow[t]{2}{*}{ Acacia crassicarpa } & $\begin{array}{l}\text { EU588664 } \\
\text { EU588643 }\end{array}$ & \multirow[t]{2}{*}{ Indonesia } \\
\hline & & KC691500 & & & & EU588653 & \\
\hline \multirow[t]{2}{*}{ C. albifundus } & \multirow[t]{2}{*}{ Acacia sp. } & $\begin{array}{l}\text { AF388947 } \\
\text { DQ371649 }\end{array}$ & \multirow[t]{2}{*}{ South Africa } & \multirow[t]{2}{*}{ C. manginecans } & \multirow[t]{2}{*}{ Mangifera indica } & $\begin{array}{l}\text { AY953385 } \\
\text { EF433310 }\end{array}$ & \multirow[t]{2}{*}{ Oman } \\
\hline & & EF070401 & & & & EF433319 & \\
\hline \multirow[t]{2}{*}{ C. atrox } & \multirow[t]{2}{*}{ Eucalyptus sp. } & $\begin{array}{l}\text { EF070417 } \\
\text { EF070433 }\end{array}$ & \multirow[t]{2}{*}{ Australia } & \multirow[t]{2}{*}{ C. manginecans } & \multirow[t]{2}{*}{ Mimusops elengi } & $\begin{array}{l}\text { AB905498 } \\
\text { AB919056 }\end{array}$ & \multirow[t]{2}{*}{ Thailand } \\
\hline & & EF070405 & & & & AB919057 & \\
\hline \multirow[t]{2}{*}{ C. atrox } & \multirow[t]{2}{*}{ Eucalyptus sp. } & $\begin{array}{l}\text { EF070414 } \\
\text { EF070430 }\end{array}$ & \multirow[t]{2}{*}{ Australia } & \multirow[t]{2}{*}{ C. moniliformis } & \multirow[t]{2}{*}{$\begin{array}{l}\text { Schizolobium } \\
\text { parahybum }\end{array}$} & $\begin{array}{l}\text { FJ151426 } \\
\text { FJ151460 }\end{array}$ & \multirow[t]{2}{*}{ Ecuador } \\
\hline & & EF070402 & & & & FJ151482 & \\
\hline \multirow[t]{2}{*}{ C. cacaofunesta } & \multirow[t]{2}{*}{ Theobroma cacao } & $\begin{array}{l}\text { DQ520637 } \\
\text { EF070428 }\end{array}$ & \multirow[t]{2}{*}{ Ecuador } & \multirow[t]{2}{*}{ C. moniliformis } & Eucalyptus grandis & $\begin{array}{l}\text { HQ203212 } \\
\text { HQ203229 }\end{array}$ & South Africa \\
\hline & & EF070399 & & & & HQ236431 & \\
\hline C. cacaofunesta & Theobroma cacao & $\begin{array}{l}\text { DQ520636 } \\
\text { EF070427 }\end{array}$ & Costa Rica & C. papillata & Annona muricata & $\begin{array}{l}\text { AY233868 } \\
\text { AY233878 }\end{array}$ & Colombia \\
\hline & & EF070398 & & & & EU241483 & \\
\hline C. coerulescens & Larix kaempferi & $\begin{array}{l}\text { KC305119 } \\
\text { KC335997 }\end{array}$ & Japan & C. papillata & Theobroma cacao & $\begin{array}{l}\text { GQ478239 } \\
\text { GQ478241 }\end{array}$ & Colombia \\
\hline & & KC405274 & & & & GQ478237 & \\
\hline C. coerulescens & Picea abies & $\begin{array}{l}\text { KC305117 } \\
\text { KC335995 }\end{array}$ & Germany & C. papillata & Theobroma cacao & $\begin{array}{l}\text { GQ478240 } \\
\text { GQ478242 }\end{array}$ & Colombia \\
\hline & & KC405272 & & & & GQ478238 & \\
\hline C. colombiana & Citrus sp. & $\begin{array}{l}\text { AY233862 } \\
\text { AY233872 }\end{array}$ & Colombia & C. paradoxa & Cocos nucifera & $\begin{array}{l}\text { JQ963886 } \\
\text { JQ963884 }\end{array}$ & Brazil \\
\hline & & EU241489 & & & & JQ963883 & \\
\hline C. colombiana & $\begin{array}{c}\text { Schizolobium } \\
\text { parahyba }\end{array}$ & $\begin{array}{l}\text { AY233861 } \\
\text { AY233873 }\end{array}$ & Colombia & C. platani & Platanus sp. & $\begin{array}{l}\text { DQ520630 } \\
\text { EF070425 }\end{array}$ & USA \\
\hline & & EU241490 & & & & EF070396 & \\
\hline C. colombiana & Citrus sp. & $\begin{array}{l}\text { AY233863 } \\
\text { AY233871 }\end{array}$ & Colombia & C. platani & Platanus sp. & $\begin{array}{l}\text { EU426554 } \\
\text { EF070426 }\end{array}$ & Greece \\
\hline & & EU241488 & & & & EF070397 & \\
\hline C. fimbriata & Ipomoea batatus & $\begin{array}{l}\text { DQ520629 } \\
\text { EF070442 }\end{array}$ & USA & C. polonica & Picea abies & $\begin{array}{l}\text { AY233907 } \\
\text { AY233932 }\end{array}$ & Austria \\
\hline & & EF070394 & & & & KC583316 & \\
\hline C. fimbriata & Ipomoea batatus & $\begin{array}{l}\text { AF264904 } \\
\text { EF070443 }\end{array}$ & $\begin{array}{l}\text { Papua New } \\
\text { Guinea }\end{array}$ & C. polychroma & Syzygium aromaticum & $\begin{array}{l}\text { AY528971 } \\
\text { AY528967 }\end{array}$ & Indonesia \\
\hline & & EF070395 & & & & AY528979 & \\
\hline C. fujiensis & Larix sp. & $\begin{array}{l}\text { KC305115 } \\
\text { AY233951 }\end{array}$ & Japan & C. populicola & Populus sp. & $\begin{array}{l}\text { EF070419 } \\
\text { EF070435 }\end{array}$ & USA \\
\hline & & KC405270 & & & & EF070407 & \\
\hline C. laricicola & Larix sp. & $\begin{array}{l}\text { KC305112 } \\
\text { KC335990 }\end{array}$ & $\begin{array}{l}\text { United } \\
\quad \text { Kingdom }\end{array}$ & C. savannae & $\begin{array}{l}\text { Pterocarpus } \\
\text { angolensis }\end{array}$ & $\begin{array}{l}\text { GU078453 } \\
\text { GU078457 }\end{array}$ & South Africa \\
\hline & & KC405267 & & & & GU078461 & \\
\hline C. manginecans & Acacia crassicarpa & $\begin{array}{l}\text { EU588665 } \\
\text { EU588644 }\end{array}$ & Indonesia & C. savannae & $\begin{array}{l}\text { Colophospermum } \\
\text { mopane }\end{array}$ & $\begin{array}{l}\text { КС691469 } \\
\text { КС691493 }\end{array}$ & South Africa \\
\hline & & EU588654 & & & & KC691517 & \\
\hline C. manginecans & Mangifera indica & $\begin{array}{l}\text { EF433304 } \\
\text { EF433313 }\end{array}$ & Pakistan & C. smalleyi & Carya sp. & $\begin{array}{l}\text { EF070420 } \\
\text { EF070436 }\end{array}$ & USA \\
\hline & & EF433322 & & & & EF070408 & \\
\hline
\end{tabular}

Table 1 (continued)

Table 1 (continued)


Table 1 (continued)

\begin{tabular}{llll}
\hline Species & Host & $\begin{array}{l}\text { GenBank } \\
\text { accession } \\
\text { number }\end{array}$ & $\begin{array}{l}\text { Geographical } \\
\text { origin }\end{array}$ \\
\hline C. variospora & Prunus sp. & EF070421 & USA \\
& & EF070437 & \\
& & EF070409 & \\
C. rufipenni & Picea glauca & KC305129 & Canada \\
& & KC336007 & \\
C. variospora & Prunus sp. & HM569655 & \\
& & EF070422 & USA \\
& & EF070438 & \\
C. virescens & Fagus americana & KF070410 & \\
& & KC305133 & USA \\
& & EF070413 & \\
\hline
\end{tabular}

The sequences in bold were generated in this study

from the neighbour-joining analysis, our C. manginecans isolate (PSU-PK01) in Mimusops elengi was closely related to C. manginecans in Mangifera indica and Acacia crassicarpa (Fig. 3 and Table 1). This sequence similarity to prior cases of $C$. manginecans corroborates the identification by phenotypic characteristics, suggesting that the causal agent of sudden decline disease on bullet wood in Thailand, represented by the PSU-PK01 isolate, should be regarded as $C$. manginecans.

To determine the pathogenicity of fungi isolated, an inoculation study was conducted on 3 month old bullet wood seedlings using an injection method. A conidial suspension was prepared by flushing 10 day old cultures with sterile DW, while the control treatment used sterile DW alone. The inoculation amount of $0.2 \mathrm{ml}$ was injected into the stem by using a disposable needle and syringe. The inoculated plants were then incubated under greenhouse conditions $\left(30{ }^{\circ} \mathrm{C}, 50 \%\right.$ relative humidity). Fungal isolates were re-isolated and re-identified using morphological characteristics for Koch's postulates confirmation. The fungi were shown to be pathogenic in young bullet wood, with plants exhibiting wilt symptoms 14 days after inoculation (data not shown). When re-isolated, the fungus was phenotypically identical to the prior isolate of $C$. manginecans (PSU-PK01).

To our knowledge this is the first confirmed record of $C$. manginecans associated with decline of $M$. elengi. Ceratocystis spp. is a species complex that has been reported worldwide, causing vascular discoloration, decline, wilt, canker and root diseases (Kile 1993). Thousands of mango trees have been killed by $C$. manginecans in Oman and Pakistan (Kazmi et al. 2005; Al Adawi et al. 2006; Van Wyk et al. 2007). The pathogen has also been reported from Indonesia (Tarigan et al. 2011). The disease may be associated with high temperatures and humidity in the local fields. Stem wounds, such as from pruning the tree to reduce branching, may be visited by insects such as Hypocryphalus mangiferae, a known vector of C. manginecans in mango (Al Adawi et al. 2013) and other beetles known to carry Ceratocystis species (Appel et al. 1990; Hayslett et al. 2005; Heath et al. 2009).

Acknowledgments The authors thank Dr. Wisut Sittichaya for photography. Prince of Songkla University is thanked for funding and facilities. The copy-editing service of RDO/PSU and the helpful comments of Dr. Seppo Karrila are gratefully acknowledged.

\section{References}

Al Adawi AO, Deadman ML, Al Rawahi AK, Al Maqbali YM, Al Jahwari AA, Al Saadi BA, Al Amri IS, Wingfield MJ (2006) Aetiology and causal agents of mango sudden decline disease in the Sultanate of Oman. Eur J Plant Pathol 116:247-254

Al Adawi AO, Al Jabri RM, Deadman ML, Barnes I, Wingfield B, Wingfield MJ (2013) The mango sudden decline pathogen, Ceratocystis manginecans, is vectored by Hypocryphalus mangiferae (Coleoptera: Scolytinae) in Oman. Eur J Plant Pathol 135:243-251

Appel DN, Kurdyla T, Lewis R Jr (1990) Nitidulids as vectors of the oak wilt fungus and other Ceratocystis spp. in Texas. For Pathol 20:412417

Glass NL, Donaldson GC (1995) Development of primer sets designed for use with PCR to amplify conserved gene from filamentous Ascomycetes. Appl Environ Microbiol 61:1323-1330

Hayslett M, Juzwik J, Camilli K, Appel D (2005) Frequencies of Ceratocystis fagacearum contaminated nitidulid beetle species in wounds on live and red oaks in Texas. Phytopathology 95:S41

Heath RN, Van Wyk M, Wingfield MJ, Roux J (2009) Insect associates of Ceratocyctis albifundus in South Africa and patterns of association in a native savanna ecosystem. Environ Entomol 38:356-364

Jacobs K, Bergdahl DR, Wingfield MJ, Halik S, Seifert KA, Bright DE, Wingfield BD (2004) Leptographium wingfieldii introduced into North America and found associated with exotic Tomicus pimiperda and native bark beetles. Mycol Res 108:411-418

Kazmi MR, Fateh FS, Majeed K, Kashkhely AM, Hussain I, Ahmad I, Jabeen A (2005) Incidence and etiology of mango sudden death phenomenon in Pakistan. Pak J Phytopathol 17:154-158

Kile GA (1993) Plant diseases caused by species of Ceratocystis sensu stricto and Chalata. In: Winfield MJ, Seifert KA, Webber JF (eds) Ceratocystis and Ophiostoma: Taxonomy, Ecology and Pathogenicity. The American Phytopathology Society, St. Paul, pp 173-183

Kollar A, Seemuler E, Bonnet F, Saillard C, Bove JM (1990) Isolation of the DNA of various plant pathogenic mycoplasma like organisms from infected plants. Phytopathology 80:233-237

Neuveglise CY, Brygoo Y, Riba G (1994) Comparative analysis of molecular and biological characteristics of strains of Beauveria brongniartii isolated from insect. Mycol Res 98:322-328

Ploetz RC (2003) Disease of mango. In: Ploetz RC (ed) Diseases of tropical fruit crops. CABI Publishing, Wallingfords, pp 327-363

Purnima A, Foti BC, Thippeswamy AHM, Jaji MS, Vishwantha Swamy AHM, Kurhe YV, Jaffar Sadig A (2010) Antiinflammatory, analgesic and antipyretic activities of Mimusops elengi Linn. Indian J Pharm Sci 72:480-485 
Tarigan M, Roux J, Van Wyk M, Tjahjono B, Wingfield MJ (2011) A new wilt and die-back disease of Acacia mangium associated with Ceratocyctis manginecans and C. acaciivora sp. nov. in Indonesia. S Afr J Bot 77:292-304
Van Wyk M, Al Adawi AO, Khan IA, Deadman ML, Al Jahwari AA, Wingfield BD, Ploetz R, Wingfield MJ (2007) Ceratocystis manginecans sp. nov., causal agent of a destructive mango wilt disease in Oman and Pakistan. Fungal Divers 27:213-230 